\title{
APHORISM AS AN OBJECT OF LINGUISTIC RESEARCH
}

\section{Ablakulov Ilkhom}

Master's Student National University Of Uzbekistan Named After Mirzo Ulugbek Tashkent, Uzbekistan

\section{ABSTRACT}

This article discusses aphorism as an object of linguistic research. The interest in the aphorism has greatly increased over the past years. This interest can be explained by the fact that aphorisms, sayings and sayings, as it is impossible, better correspond to the atmosphere of our time, which requires a special laconicism and formulation of ideas.

KEYWORDS: - Aphorism, special laconicism, formulation of ideas

\section{INTRODUCTION}

Elements of aphoristic thinking make it possible to single out something extremely significant in a large amount of information for the purpose of cognition, to find and determine your personal position. The aphoristic expression generalizes and typifies various manifestations of individual and social existence and firmly exists in communication as its organic part, as a capacious and co-centered model of the figurative display of reality and the expression of the attitude of the language to it (1).

\section{THE MAIN RESULTS AND FINDINGS}

Aphorisms have always attracted the attention of people, but at the present time, in the era of scientific and technological progress, their importance in particular has increased; it is no coincidence that at present in a number of countries aphoristics is actively developing, and in some places, it has reached its peak. Against the background of an almost absolute absence of literary works in the past, a number of substantive theoretical articles on aphorisms have recently been published; there are also works of a linguistic nature. Problems of aphoristics are considered at literary congresses, and numerous researches are devoted to them.

This kind of interest in the aphorism that, by virtue of their universality, the aphorisms of the era, they 
CURRENT RESEARCH JOURNAL OF PHILOLOGICAL SCIENCES 2(12):

67-70, December 2021

DOI: https://doi.org/10.37547/philological-crjps-02-12-14

ISSN 2767-3758

(C)2021 Master Journals

Crossref d

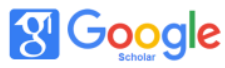

Accepted09th December, 2021 \& Published 14 ${ }^{\text {th }}$ December, 2021

are equally close to science, and appeared as a result of meeting the atmosphere with art, they organically interact the principles of scientific and artistic creativity (2).

Almost all outstanding scientists were at the same time the creators of aphorisms. Let us recall the ancient scientist - the ancestor of aphoristics Hippocrates and the authors of the aphoristic books Pascal, Goethe, Lichtenberg, who were remarkable scientists of their time (3. 36, p. 27). Aphorism is associated with science, as well as with art, being, as it were, a kind of link between them. Expressiveness and imagery bring the aphorism closer to fiction, the property of the synthesis of thoughts, the establishment of a connection between phenomena, accuracy and laconicism make them related to science (31).

It is not by chance that there are still supporters of the theory that aphorisms belong not to literature, but to science abroad, in particular to philosophy, and there is a debate on this issue. Aphorisms, of course, should be considered a literary genre, but they are close to science, and this contributes to their popularity in our time, characterized by the flourishing of science (4.37).

The importance of aphorisms, their ancient origins and widespread use cannot be denied. But despite the fact that a large number of literary people are devoted to the genre of aphorisms, ideas about it are very vague, do not have clear outlines. There are a number of problems that remain unsolved: the word "aphorism" itself has no generally accepted concept; not established genre boundaries and specific features of aphorisms; there is no generally accepted classification of aphoristic statements, their functions in various types of texts (5.7).

The concept of an aphorism, its perception may vary depending on the cultural and historical background and scientific context, as well as on the position of the researcher. Each author gives his own clear definition of the aphoristic genre. There are many different definitions proposed by different scientists. Some people characterize the aphorism as a short but deep in content judgment, others believe that this is a paradoxical judgment in a sophisticated style, tending primarily to originality. Someone considers an aphorism as «a small form text that implicitly contains broader information than that which is explicitly expressed» $(6.16, \mathrm{p}$. 105).

An aphorism is a concise, terse, laconic, or memorable expression of a general truth or principle They are often handed down by tradition from generation to generation.

The concept is generally distinct from those of an adage, brocard, chiasmus, epigram, maxim (legal or philosophical), principle, proverb, and saying; although some of these concepts may be construed as types of aphorism.

First of all, it is necessary to understand the etymology of the word aphoristics. Aphoristics («from the Greek. Aphorismos - definition. Short

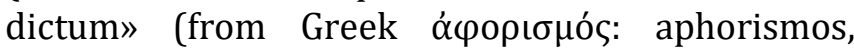
denoting 'delimitation', 'distinction', and 'definition') (7.42). In the Greek language there was a word aphorismos - that is, a short dictum, definition, ... (8. 46). The main concept on which it relies and operates aphorism, is the concept of aphorism. The distinctive features of an aphorism are usually described by comparing it with phenomena and concepts that are close or contiguous in some way.

In encyclopedias, reference books and other scientific literature, you can find many different definitions of this phenomenon, which differ not only in specific features, but also in basic 
CURRENT RESEARCH JOURNAL OF PHILOLOGICAL SCIENCES 2(12):

67-70, December 2021

DOI: https://doi.org/10.37547/philological-crjps-02-12-14

ISSN 2767-3758

(C)2021 Master Journals

Crossref d

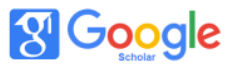

Accepted09th December, 2021 \& Published 14 ${ }^{\text {th }}$ December, 2021

characteristics. Let's consider the most indicative definitions for comparison.

Aphorism:

1) a short expressive dictum containing a generalizing conclusion; catch phrase (9. 4, p. 20);

2) generalized, complete and profound thought of a certain author. expressed in a laconic, polished form, distinguished by a mark of expressiveness and a clear surprise of judgment. Like the proverb, the aphorism does not prove, does not argue, but affects the consciousness with the original formulation of thought (10. 3, p. 19);

3) a judgment of a general nature, expressed in a laconic artistic form and), as a rule, belonging to a certain author (11.28);

4) a short saying, a complete thought, expressed in a concise, precise form. These are Russian folk proverbs (12.34).

The form and function of the aphorism is most clearly expressed in its shortest definition, proposed in the «Explanatory Dictionary of the Russian Language» edited by D.Sc. Ushakova: «aphorism (gr. Aphorismos definition) - a short expressive saying» (13.35)

Definitions from foreign sources give a more indepth understanding of this concept, highlighting additional characteristics of the aphorism.

The Oxford Dictionary offers the following definition (14.49):

1. A pithy observation which contains a general truth 'the old aphorism 'the child is father to the man' ' (a capacious, laconic pop out, containing a well-known truth)

2. A concise statement of a scientific principle, typically by a classical author: 'the opening sentence of the first aphorism of Hippocrates' (a summary of the scientific principle usually by the classical author).

The electronic dictionary dictionary.com defines the aphorism as (15. 48):

1. a terse saying embodying a general truth, or astute observation (a short saying that represents a well-known truth or an insightful observation)

Definition of aphorism from the Cambridge Dictionary (16. 41):

1. a short clever saying that is intended to express a general truth (a short, wise statement designed to convey a common knowledge)

\section{Conclusion}

Comparing the following definitions from sources in English, with the definitions of the word "aphorism" in Uzbek, the following differences can be distinguished: firstly, in English dictionaries, an aphorism is simply a briefly expressed and easily remembered principle or truth, while in Uzbek language sources a characteristic for aphorisms, originality, well-aimed levelness and obvious unexpectedness of judgments. Secondly, foreign sources do not mention at all that proverbs and sayings belong to the aphorism; in some Uzbek dictionaries, aphorisms are identified with proverbs. It should also be noted that an aphorism can be a summary of a scientific principle, according to the information in the Oxford Dictionary, but this is not mentioned in Uzbek-language sources.

\section{REFERENCES}

1. Antipova A.P. To the question definition of aphorisms / Antipova A.P. // Linguistics. Collection of articles , issue 2.Smolensk,2001,/,- p.135.

2. Ivanov E.E. Aphorism as an object of linguistics the Main properties// Vestnik of Russia University. Theory of languages. Semiotics. Semantics. 2020. T. p.659-706. 
CURRENT RESEARCH JOURNAL OF PHILOLOGICAL SCIENCES 2(12):

67-70, December 2021

DOI: https://doi.org/10.37547/philological-crjps-02-12-14

ISSN 2767-3758

(C)2021 Master Journals

Crossief dof Bongle

Accepted09th December, 2021 \& Published 14 ${ }^{\text {th }}$ December, 2021

3. Brokgauz F.A. Aphorisms//Encyclopedic dictionary. Sankt Peterburg1891.

4. merriam-webster.com

5. dictionary.cambridge.org

6. examples.yourdictionary.com

7. wikipedia.org

8. goodreads.com

9. literarydevices.net

10. newyorker.com

11. litcharts.com 